\title{
Analysis of Factors Affecting Human Development Index East Java
}

\author{
Niniek Imaningsih ${ }^{1}$, Wiwin Priana $^{2}$, Sishadiyati $^{3}$, Kiky Asmara $^{4}$, Riko Setya Wijaya ${ }^{5}$ \\ \{niniekimaningsih@gmail.com ${ }^{1}$, wiwinpriana10@ gmail.com ${ }^{2}$, ratihsishadiyati@gmail.com ${ }^{3}$ \\ rikosetyawijaya.80@gmail.com ${ }^{4}, \underline{\text { kikyasmara25@gmail.com }}{ }^{5}$ \} \\ 1,2,3,4,5 Progdi Ekonomi Pembangunan Universitas Pembangunan Nasional "Veteran” Jawa \\ Timur, Indonesia
}

\begin{abstract}
The Human Development Index is calculated based on the geometric mean of the health index, the knowledge index, and the expenditure index. The calculation of these three indices is done by standardizing the minimum and maximum values of each index component. Therefore, the increase in HDI achievement is inseparable from the improvement of each component. By looking at the achievements of each component, it is hoped that the Regional Government will get input to improve human development in their respective regions. The report from the Central Statistics Agency said that the quality of human life in East Java in the last five years, which was shown through the HDI value, was relatively increased by 68.95 in 2015 compared to 2011 which was 66.06 but still below the national IPM of 69.6. During the period 2011 to 2015, East Java has succeeded in increasing life expectancy at birth from 69.86 in 2011 to 70.68 in 2015, on average the life expectancy grew by 0.21 years per year. the same, the average length of schooling in East Java grows 0.09 years each year, this shows that in general the average population of East Java aged 25 years and over has been educated to grade VII (junior class I). This positive growth is an important capital to support development in East Java.HDI components increases above also driven by several factors that affect the HDI among other shopping areas per capita, the dependency ratio, Gini Ratio and non-food expenditure per capita. The role of government in the allocation of regional spending for health and education plays an important role in improving the components of the HDI. Based on the description above, researchers are interested in conducting research.
\end{abstract}

Keyword: Life Expectancy, Average Length of School, Gini Ratio, Non-Food Expenditure, Dependency Ratio

\section{Introduction}

The progress of a country at the macro level can be obtained from a useful contribution. To achieve the ultimate goal of development, namely the welfare of the people, humans are expected to be the subject of development and not just as objects. The United Nations Development Program (UNDP) states that human development is a process of obtaining various choices that humans have as published by the Human Development Report (HDR) for the first time in 1990 (Rustariyuni 2014). Whereas the Human Development Index (HDI) it self established by UNDP in 1996 was developed by Amartya Sen in 1999 in a book titled Development as Freedman (Sen 1999). 
UNDP measures welfare by compiling a composite index based on three indicators, namely: life expectancy at birth, adult literacy rate, mean years of schooling and mean years of schooling purchasing power parity. Life expectancy indicators measure health, adult population literacy indicators and average length of schooling measure education and purchasing power indicators measure life standards (Hopkins 1991).

In 1990 the United Nations Development Program (UNDP) also emphasized clearly the main message contained in every report on human development at the global, national and regional levels, namely human-centered development, which places humans as the ultimate goal of development, and not as a tool for development (Statistik 2009).

With that in this study aims to analyze several factors that influence life expectancy and the average length of the school, among others Gini Ratio, Expenditure and Ratio of non food addiction.

\section{Operational Definition and Measurement Procedures Human Development Index}

The Human Development Index (HDI) as a decomposite indicator used as a measure of welfare developed by the United Nations Development Program (UNDP) based on the idea of Haq (1996). In describing the development of human development in a measured and representative manner UNDP in 1990 introduced and developed an indicator called the Human Development Index (HDI). The Human Development Index is in the range of 0 to 100 . If the HDI number is close to 100 , it shows that HDI is getting better.

\section{Life expectancy}

Life Expectancy $(\mathrm{AHH})$ is one indicator used to assess the health status of the population. According to Statistics Indonesia, life expectancy at birth (life expectancy at birth) is the average year of life that will be lived by a newborn baby in a certain year. Life Expectancy in one region is different from other regions depending on the quality of life that can be achieved by the population (Sugiantari dan Budiantara 2013).

The quality of life of a country or region reflects the welfare of the people and the success of programs made by the government to improve the degree of human life. Related to quality of life there is an element of life expectancy (AHH) in it. Life expectancy is one indicator that is used to assess the health status of the population that describes the quality of life (Ardianti et al. 2015).

Can be calculated using the indirect approach (indirect estimation). There are two types of input data that are used to calculate Life Expectancy, namely the value of a live birth rate data and the child is still alive. The Mortpack program package was chosen by the Trussel method with the West model, which is in accordance with the essence of population and conditions in Indonesia. 


\section{The Average Length-School}

States that education is a fundamental development goal. Where education plays a key role in shaping a country's ability to absorb modern technology and to develop capacity to create sustainable growth and development (Todaro dan Stephen 2000).

The average length of school indicates the higher level of formal education achieved by the community in an area. The higher the average length of school means the higher level of education undertaken. The average length of school is the average number of years spent by residents aged 15 years and over at all levels of formal education followed. To increase the average length of schooling, the government has launched a 9-year compulsory education program or basic education up to junior high school level (Nugroho dan PURWANTI 2011).

To get a job offered in the modern sector is based on one's level of education and the level of income he has during life is positively correlated to his level of education. This income level is strongly influenced by the length of time a person attains education (Todaro dan Stephen 2000).

Mean years at schooling is one indicator used to measure the dimensions of population knowledge. Means years at schooling illustrates the number of years used by occupants aged 15 years and over in undergoing formal education.

\section{Gini Ratio}

On the problem of income distribution and poverty, a simple approach can be adopted, namely using a framework of production possibilities (Todaro dan Smith 2006). Production in an area or country can be divided into two groups of goods, namely for basic needs (food, drink, clothing and housing) and luxury goods for problems that occur. The assumption used is that all factors of production are fully utilized. To provide an overview of the problems caused by the community who determine the combination of goods to be produced, funds are selected. Then figure 1 gives a picture of this problem.

\section{Figure 1. Production Possible Curve}

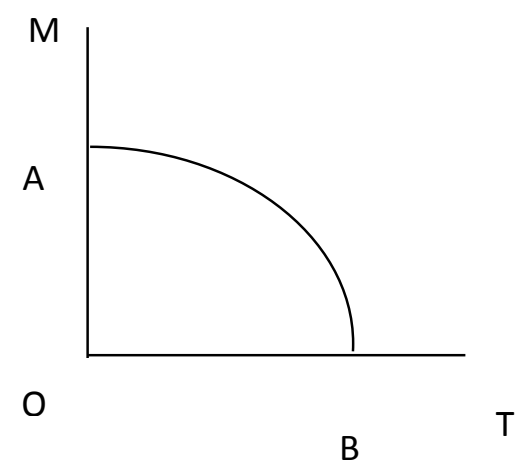


The possible production curve above shows the position of the combined points of the enis produced goods to the maximum. The vertical axis shows the quantity of luxury goods production, for the horizontal axis shows the staple goods. Points A and B describe the combination of production of luxury goods and basic necessities in the same level of income. Point A shows that more luxury goods are produced compared to basic needs. Whereas point $\mathrm{B}$ is more staple goods produced by the community than luxury goods.

\section{Non-Food Expenditures}

Household expenditure differentiated according to the group food and non-food. To illustrate the welfare of a household can be seen from the size of the proportion of expenditure for food consumption to all household expenses. Households with larger consumption expenditure on food consumption is indicated as low-income households. The higher the household income, the proportion of household spending will be smaller. So that the level of income of the community can be projected with the proportion of non-food expenditure (Statistik 2008).

So it can be said that between non-food expenditure and the proportion of food expenditure has a negative relationship. Thus, expenditure patterns can be used to measure the level of welfare of the population, which changes are used as a guide to changes in welfare levels.

Non-food expenditure such as for education, health and entertainment carried out by residents of districts / cities with low poverty levels should be greater than districts / cities with higher poverty levels (Subarna 2012).

\section{Dependency Ratio}

Dependency ratio is a comparison of the number of unproductive age population (Kurniawati 2016). If the dependency ratio is high, the HDI (in which there is life expectancy and average length of school) is low because of the many burdens that must be borne by the productive age to bear the non-productive age. Household expenditure has a direct contribution to human development, such as food, health and education. So that households play an important role in human development.

The dependency ratio is calculated by using the formula:

$$
\mathrm{DR}=\frac{P(0-14)+P(65+) X 100}{P(15-64)}
$$

\section{Explanation :}

DR

$$
=\text { Dependency Ratio }
$$

$$
\begin{aligned}
& =\text { Number of Population Ages 0-14 years } \\
& =\text { Number of Population Aged 65+ years } \\
& \quad=\text { Number of Population Ages } 15-64 \text { years }
\end{aligned}
$$


The dependency ratio is based on the habits proposed by Modigliani and Brumberg (1954) and Ando and Modigliani (1963) in (Richard 2004) it is assumed that the age or age of the community influences the pattern of consumption behavior. Dissaving can be closed by saving years.

When a baby is born he already has life needs that must be fulfilled, even though he has not been able to participate in the formation of maximum production, it means that his income is with the amount of positive consumption expenditure compelling someone to do dissaving. When he grows up and enters the workforce he has savings because he earns income. Then dissaving will occur again during retirement because it becomes a burden to the burden of life for others (AFIFAH 2017).

\section{Research methods}

This research is a literature study by analyzing secondary data with Gini Ratio, Non-Food Expenditure, Dependency Ratio, Life Expectancy and Average Length of School. The spatial scope of the study is East Java Province with a data series of 10 years from 2009 to 2017. The data used in this study were taken from several publications published by the Central Statistics Agency (BPS) of East Java.

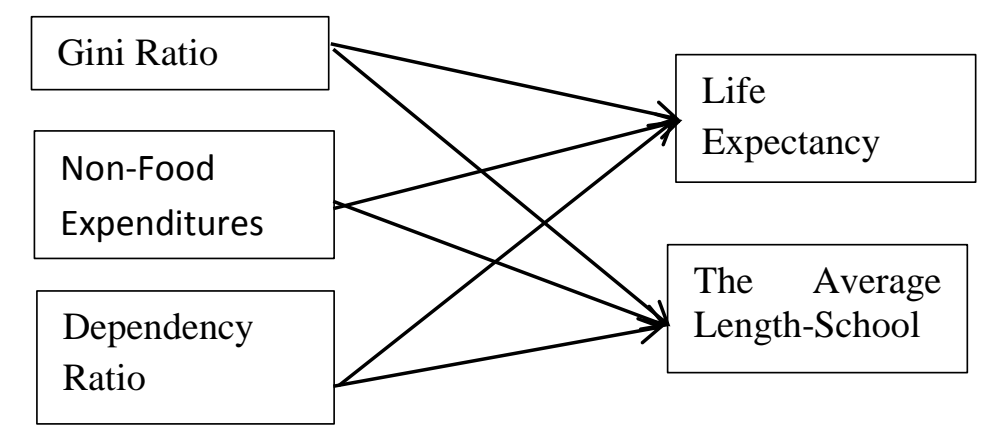

\section{Analytical Techniques}

The data that has been collected, analyzed using multiple linear regression analysis in accordance with the ranking of research, with the SPSS program. The regression model in this study uses the dependent variable Human Development Index (HDI) (Y1) and Average Length of School (Y2), while the independent variables are Gini Ratio (X1), Non-Food Expenditure (X2) and Dependency Ratio (X3). The mathematical functions are as follows:

$\mathrm{Y} 1=\mathrm{f}(\mathrm{X} 1, \mathrm{X} 2, \mathrm{X} 3)$ 


\section{Results and Discussions}

\section{Results}

The estimated equation of the regression model of the results of the analysis of variables that affect the Human Development Index (HDI) in East Java for the period 2009 - 2017 is as follows:

$$
Y=69,186-0,222 \times 1+0,00000453 \times 2-0,007 \times 3
$$

While the estimated equation of the regression model of the results of the analysis of variables that affect the average length of school in East Java for the period $2009-2017$ is as follows:

$$
\mathrm{Y}=\mathbf{7 , 5 4 3}-\mathbf{3 , 9 1 9} \mathrm{X} 1+\mathbf{0 , 0 0 0 0 0 3 6 1} \mathrm{X} 2+0,006 \mathrm{X3}
$$

From the results of the analysis of the influence or relationship simultaneously (in unison) used the F test it can be concluded that the variable Gini Ratio (X1), nonFood Expenditures (X2), and Dependency Ratio (X3) influence together on the variable Life Expectancy (Y1) with significant of $0.002<0.05$ and for the average length of school (Y2) with a significance of $0.001<0.05$ these results can be concluded that, the independent variables affect overall or together on the dependent variable

This test is used to determine the significant effect of independent variables individually on the dependent variable. The results of the $t$ test in this study are explained as follows:

\section{t Test Analysis Results}

\begin{tabular}{|l|l|l|l|l|}
\hline \multicolumn{1}{|c|}{ Variabel } & \multicolumn{1}{|c|}{$\begin{array}{c}\text { t test } \\
\left(\mathbf{Y}_{\mathbf{1}}\right)\end{array}$} & \multicolumn{1}{c|}{ Sig. } & $\begin{array}{c}\text { t test } \\
\left(\mathbf{Y}_{\mathbf{2}}\right)\end{array}$ & \multicolumn{1}{c|}{ Sig. } \\
\hline Gini Ratio $\left(\mathrm{X}_{1}\right)$ & $-0,041$ & 0,968 & $-1,592$ & 0,162 \\
\hline Non-Food Expenditures $\left(\mathrm{X}_{2}\right)$ & 2,403 & 0,053 & 4,110 & 0,006 \\
\hline Dependency Ratio $\left(\mathrm{X}_{3}\right)$ & $-0,085$ & 0,935 & 0,147 & 0,888 \\
\hline
\end{tabular}

\section{Discussion}

From the results of the analysis above the Gini ratio which shows the inequality of income distribution has no effect but has a negative relationship towards the life expectancy. The higher the income distribution inequality, the lower the life expectancy in East Java. This is due to the government's role in determining the scale of development priorities in East Java, which is more focused on public health insurance programs. 
Non-food expenditure has an influence and has a positive relationship with life expectancy in East Java. The higher the non-food expenditure, the higher the life expectancy, namely the higher the level of household income, the higher the proportion of food expenditure to all household expenses.

Dependency ratio that shows the burden borne by individuals at productive age has no effect but has a negative relationship towards the life expectancy, the higher the dependency ratio, the lower the life expectancy in East Java. This is in accordance with existing theories, because in reality the average individual aged between 15-20 years is still a burden of productive age dependents above, besides the creation of economic independence in the community through family communal efforts in the digital age helps to increase life expectancy in East Java.

The Gini ratio which shows the inequality of income distribution has no effect but has a negative relationship towards the average length of schooling. The higher the income distribution inequality, the lower the average length of schooling in East Java. This is due to the government's role in determining the scale of development priorities in East Java focused on programs in the field of education through school operational assistance.

Non-food expenditure has no effect and has a negative relationship with the average length of schooling in East Java. The higher non-food expenditure, the lower the average length of schooling. The low average length of schooling is influenced by consumption factors and people's lifestyles. (Baudrillard 2012) states, the situation of contemporary society is shaped by the fact that humans are now surrounded by consumption factors. In fact humans will never feel satisfied with their needs. (Baudrillard 2012), the rationality of consumption in the system of consumer societies has changed considerably, because at this time people buy goods not as an effort to meet needs (needs) but rather as fulfillment of desires.

The dependency ratio has no effect and has a positive relationship with the average length of school, the higher the dependency ratio, the higher the average length of schooling in East Java. This is consistent with the life cycle model (Life-Cycle Model) for consumption habits and savings expressed (Modigliani dan Brumberg 1954).

\section{Conclusions}

From the discussion in the previous chapter can be concluded that simultaneously variable Gini ratio, non-food expenditures and dependency ratios affect life expectancy and the average length of school in East Java with the positive and negative directions. However, individually only the variable expenditure that affects the life expectancy and average length of schooling in East Java.

The above shows that the role of the East Java government in human development, particularly in the health and education sectors over a ten year period showed a fluctuating increase. The increase was supported by government programs that had a 
positive impact on human development, which was illustrated through the achievement of the human development index in East Java.

In an effort to increase life expectancy and the average length of schooling in East Java Province, a budgeting policy is needed by increasing the composition of the expenditure budget so that it is more focused on the target program, and reducing supporting spending as well as program implementing partners. The intended target program is in the education sector because it is a crucial sector to improve the human development index, as well as to build public facilities in the health sector, such as the construction of hospitals, medical center, and unified postal service as well as improving the quality of nutrition and nutrition for the poor, especially in rural areas and disadvantaged areas.

\section{References}

AFIFAH, N. 2017. "Pengaruh produk domestik bruto (pdb) dan indeks pembangunan manusia (ipm) terhadap jumlah penghimpunan dana zakat, infaq dan shadaqah (zis) di indonesia tahun 2010-2015". Vol., No., hlm.

Ardianti, A. V., S. Wibisono, dan A. Jumiati. 2015. "Faktor-faktor yang mempengaruhi angka harapan hidup di kabupaten jember". Skripsi. Jember: Program Studi Ekonomi Pembangunan Universitas Jember, Vol., No., hlm.

Baudrillard, J. 2012. Impossible exchange: Verso Trade.

Hopkins, M. 1991. "Human development revisited: A new undp report". World Development, Vol. 19, No. 10, hlm 1469-1473.

Kurniawati, T. 2016. "Analisis pengaruh pertumbuhan ekonomi, jumlah pengangguran dan indeks pembangunan manusia (ipm) terhadap jumlah penduduk miskin di propinsi jawa barat". Vol., No., hlm.

Modigliani, F., dan R. Brumberg. 1954. "Utility analysis and the consumption function: An interpretation of cross-section data". Post-keynesian economics, Vol. 1, No., hlm 338-436.

Nugroho, W., dan E. Y. PURWANTI. 2011. "Analisis pengaruh pdrb, agrishare, ratarata lama sekolah, dan angka melek huruf terhadap jumlah penduduk miskin di indonesia", Universitas Diponegoro.

Richard, P. A. 2004. "The economics of adjustment and growth". Editorial UPR. Los Angeles, Vol., No., hlm.

Rustariyuni, S. D. 2014. "Pengaruh gini ratio, pengeluaran non makanan per kapita, belanja daerah dan laju pertumbuhan ekonomi pada indeks pembangunan manusia kabupaten/kota di provinsi bali periode 2004-2012". PIRAMIDA, Vol. 10 , No. 1 , hlm.

Sen, A. K. 1999. Development as freedom (1st. Edn.; new york: Knopf) xvi.

Statistik, B. P. 2008. Statistik indonesia. Biro pusat statistik. Jakarta. 2009. Analisis kemiskinan, ketenagakerjaan dan distribusi pendapatan: Jakarta.

Subarna, T. 2012. "Analisis kemiskinan dan pengeluaran non-pangan penduduk jawa barat". Jurnal Bina Praja: Journal of Home Affairs Governance, Vol. 4, No. 4, hlm 243-250.

Sugiantari, A. P., dan I. N. Budiantara. 2013. "Analisis faktor-faktor yang mempengaruhi angka harapan hidup di jawa timur menggunakan regresi 
semiparametrik spline". Jurnal Sains dan Seni ITS, Vol. 2, No. 1, hlm D37D41.

Todaro, M. P., dan S. C. Smith. 2006. "Pembangunan ekonomi". Jakarta: erlangga, Vol., No., hlm.

Todaro, M. P., dan C. S. Stephen. 2000. "Pembangunan ekonomi di dunia ketiga edisi ketujuh". Jakarta: erlangga, Vol., No., hlm. 